\title{
Fractionation of Fulvic And Humic Acid On Andisol Based On Altitude Under Organic Arabica Coffee At Bener Meriah District, Aceh Province
}

\author{
Abubakar Karim, Darusman, and Hifnalisa \\ Lecturers at Soil Science Department, Faculty of Agriculture, Syiah Kuala University. \\ Banda Aceh, Indonesia \\ \{darusman@unsyiah.ac.id\}
}

\begin{abstract}
The formation of humic substances (humic acid, fulvic acid, and humin) which comprise the majority of soil organic matter, still needs to be clarified because these very complex processes may involve numerous organic components as starting materials, as well as many reactions such as oxidation, polymerization, condensation, and hydrolysis. Altitude-based soil samples were taken from the organic coffee plantation at Bener Meriah District, Bandar and Bukit subdistrict, Aceh Province, Indonesia. Soil types are Aquic Hapludand (alt. <1,000 m asl), Typic Hapludand (alt. $900-1,600 \mathrm{~m}$ asl), and Typic Durudand (alt. $>$ $1,500 \mathrm{~m}$ asl). Descriptive methods followed by field investigation and laboratory analysis were used. The lands were planted since 1992 consisting of two subdistricts (Bandar and Bukit), Bener Meriah District, Aceh Province, $\left(96^{0} 51^{\prime} 41^{\prime \prime}-96^{\circ} 59^{\prime} 44^{\prime \prime} \mathrm{E}\right.$ and $\left.4^{0} 42^{\prime} 49^{\prime \prime}-4^{0} 50^{\prime} 27^{\prime \prime} \mathrm{N}\right)$. Research objects were open land spaces planted by Arabica coffee plants covering all communities' coffee plantation in Bandar and Bukit subdistricts, Bener Meriah Districts. Arabica Coffee plantations at Bandar and Bukit Subdistricts with variety of catimor jaluk, plants density 2,500 plants per hectare, age 15 years have been managed organically since 1992 . The soil profile was made on each measurement point, and each soil horizon of it, soil samples were taken for Humic substances (HA and FA) analysis and chemical analysis ( $\mathrm{pH}, \mathrm{CEC}$, and organic $\mathrm{C}$ ). Our results showed that the content of fulvic and humic acid differs on each horizon and among altitudes. Humic acid content on the surface horizon ranges from low to high. The highest humic acid content was found on the surface horizon at an altitude of 1,050 $\mathrm{m}$ asl. The higher the altitude, the humic acid content decreases on the surface horizon.
\end{abstract}

Keywords: Fulvic Acid, Humic Acid, Andisol, Altitude, Slope, Organic Arabica Coffee

\section{Introduction}

Andisol is also called a Andisol organic matter because the soil is dominated by organic matter. Soil organic matter plays important roles in soil health. Enhancing soil organic matter can improve soil quality, i.e., increasing nutrient retention, improving soil structure, enhancing soil biotic activity and improving soil moisture and temperature regimes. Andisol's parent material is derived from volcanic ejecta and makes it different soil properties from other soil formed parent [1]. The decay of soil organic matter from andisol provides a huge amount of $\mathrm{CO} 2$ into the atmosphere and may cause a change in climate [2]. The attention of organic matter stored in the soil profile has been attracted by a lot of scientists because it has been promoted for the mitigation of climate change. However, when the soil organic carbon content falls below 1 percent, the soil is in endangered, because the soil aggregates become destabilize and soil nutrient cycling is compromised [3]. Increasing carbon in the soil should still be pursued for improving soil structure, atmospheric $\mathrm{CO} 2$ attenuation, and nutrient cycling.

Humic substances found in Andisol, the major organic constituents of soils and sediments, are widely distributed over the earth's surface, occurring in almost all terrestrial and aquatic environments. Approximately $60-70 \%$ of the total soil-C occurs in humic materials [4]. Important characteristics of humic substances are their ability to form water-soluble and water-insoluble complexes with metal ions and hydrous oxides and to interact with clay minerals and organic compounds such as alkanes, fatty acids, pesticides, etc. Of special concern is the formation of water-soluble complexes of fulvic acids (FA'S) with toxic metals and organics which can increase the concentrations of these constituents in soil solutions and in natural waters to levels that are far in excess of their normal solubilities.

According to Schnitzer [5] a large variety of organic materials in soils can be grouped into humic and nonhumic substances. The latter include those whose physical and chemical characteristics are still recognizable, such as carbohydrates, proteins, peptides, amino acids, fats, waxes, and low-molecular-weight organic acids. Most of these compounds are attacked relatively readily by microorganisms and have usually only a short life span in soils and sediments. By contrast, humic substances exhibit no longer specific physical and chemical 
characteristics (such as a sharp melting point, exact refractive index, and elementary composition, definite IR spectrum, etc.) normally associated with well-defined organic compounds.

Yanagi, Nishimura, \& Shindo [6] mentioned that soil organic matter was classified into humic and non-humic substances. Humic substances have been divided into humic acid (HA, alkali-soluble and acid-insoluble), fulvic acid (FA, alkali- and acid-soluble), and humin (alkali-insoluble) fractions. The mechanisms that underlie the formation of humic substances, which comprise the majority of SOM (soil organic matter), still need to be clarified because these very complex processes may involve numerous organic components as starting materials, as well as many reactions such as oxidation, polymerization, condensation, and hydrolysis

Bener Meriah District, Aceh Province, Indonesia lies on 750 till 3,000 m above sea level with annual rainfall $1,700-2,500 \mathrm{~mm}$. Dominant soils found are Andisol characterized by highly porous, dark-colored soil, lower bulk density, and exchangeable complex is dominated by amorf. Rapid weathering of the porous parent material results in allophanic compounds (allophane and imogolite). These hydrous aluminosilicates give peculiar properties to volcanic soils such as variable charge, high water retention, low bulk density and highly stable aggregates [1], [7]. Kimsey, Garrison-Johnson, \& Johnson [8] said that soil property characterization indicated that surficial ash soils often reflect the physical and mineral characteristics of subsurface soils, but climatic conditions control their chemical expression through the degree of mineral weathering. Bartoli, Poulenard, \& Schouller [9] found total specific surface area andisol (SSAs) were positively related to micropore SSA. The more allophanic the Andisol horizon sample, the larger were its total, micropore, and mesopore SSAs.Humic substances (HA and FA) are playing an important role in soil fertility, crop productivity and they are relatively resilient to erosion and compaction [1].

Therefore, crop development and mobility of nutrient are influenced. In order to get more benefits from this volcanic soils (Andisol), knowledge management of Andisol must be practiced. The objectives of this study were to evaluate status and behavior humic and fulvic acid in Andisol at the coffee plantation which organically managed.

\section{Materials and Methods}

The research was conducted in Soil physics and chemistry laboratory, Faculty of Agriculture Syiah Kuala University Banda Aceh Indonesia since July - November 2014. Altitute-based soil samples were taken from the organic coffee plantation at Bener Meriah District, Bandar and Bukit subdistrict, Aceh Province, Indonesia. Soil types are Aquic Hapludand (alt. $<1,000 \mathrm{~m}$ asl), Typic Hapludand (alt. $900-1,600 \mathrm{~m}$ asl), and Typic Durudand (alt. $>1,500 \mathrm{~m}$ asl) [10].

Descriptive methods followed by field investigation and laboratory analysis were used in this study. Reseach focus was arabica organic plantation. The lands were planted since 1992, consisting of two subdistricts (Bandar and Bukit), Bener Meriah District, Aceh Province, (960 51' 41" - 960 59'44" E and $4042^{\prime} 49^{\prime \prime}-40$ 50' 27" N). Land suitability evaluation for organic coffee plantation in Andisol was conducted during March 1997 till Feb 1999.

Soil samples were taken from community coffee plantation based on the altitude at Bandar and Bukit, Bener Meriah Sub District. Karim et al [10] found that soil types at sites were Aquic Hapludand (alt $<1,000 \mathrm{~m}$ asl), Typic Hapludand (alt. 1,000 - 1,500 m asl), and Typic Durudand (alt. $>1,500 \mathrm{~m}$ asl). Tools used in this research are maps, compass, Abney level, altimeter, soil munchel color chart, augers, hoes, knives, and other related tools.

Research objects were open land spaces planted by Arabica coffee plants since 1992 [11] covering all communities coffee plantation in Bandar and Bukit subdistricts, Bener Meriah Districts. Soils were sampled at the following sites:

1. Arabica Coffee plantations at Bandar and Bukit Subdistricts with variety of catimor jaluk, plants density 2500 plants per hectare, age 15 years managed organically since 1992.

2. Altitude class; seven classes applied i.e $900-1,000 \mathrm{~m}$ asl (P1) with slopes $>30 \% ; 1,000-1,100 \mathrm{~m}$ asl (P2) with slopes 8 - 15\%; 1,100 - 1,200 m asl (P3) slopes $0-3 \% ; 1,200-1,300 \mathrm{~m}$ asl (P4) slopes $0-3 \% ; 1,300$ 1,400 $\mathrm{m}$ asl (P5) slopes 0 - 3\%; $1.400-1,500 \mathrm{~m}$ asl (P6) slopes 8 - 15\%; and 1,500 - 1,600 m asl (P7) with slopes $>30 \%$.

The soil profile was made on each measurement point, and each soil horizon of it, soil samples were taken for Humic substances (HA and FA) analysis and chemical analysis ( $\mathrm{pH}, \mathrm{CEC}$, and organic-C). Humic substances were analyzed according to Tan procedure [12]. 


\section{Result And Discussion}

Our general finding in term of field observation showed similarities and differences in the natures of the seven soil profiles.

\section{a. Soil Acidity}

We measured soil acidity $(\mathrm{pH})$ in forms of $\mathrm{pH}(\mathrm{H} 2 \mathrm{O})$ and $\mathrm{pH}(\mathrm{KCl})$. As stated by Nanzyo, Dahlgren, \& Shoji [13] the $\mathrm{pH}(\mathrm{KCl})$ values provide a measure of acidity in Andisols and are usually lower than $\mathrm{pH}(\mathrm{H} 2 \mathrm{O})$. Crop growth is influenced by soil acidity and each crop requires a specific $\mathrm{pH}$ for growing and good yielding. In general, crops have wide ranges in $\mathrm{pH}$ tolerance with the condition nutrients are available. $\mathrm{pH}$ influences the availability of $\mathrm{Ca}, \mathrm{Mg}, \mathrm{Al}, \mathrm{P}$, and other nutrients. Our study showed that general soil acidity was found in a range of 5.50 to 6.50. Soil pH (H2O) at Profile P1 (950 m asl), horizon $\mathrm{Ah}$ is 5.80, and $\mathrm{pH}(\mathrm{KCl})$ is 4.50 (Table 1). Nanzyo et al.[7] stated that there is considerable number allophanic Andisols and show $\mathrm{pH}(\mathrm{H} 2 \mathrm{O})$ values of 5.80 to 6.00 , although the base saturation of these soils is 10 percent or less.

The deeper the soil, the lower the soil $\mathrm{pH}$. But, at profile $\mathrm{P} 2(1,050 \mathrm{~m}$ asl) soil $\mathrm{pH}$ increased with the increase of soil depth. The value of $\mathrm{pH}$ on the surface horizon showed lower at profile P1 (4.55). This is in line with the higher organic content on the soil surface. Although there are a variety of soil components contributing to soil acidity [14], [15] panic clays, 2:1 layer alumino silicates, and humus are especially important in most Andisols.

The values of $\mathrm{pH}(\mathrm{H} 2 \mathrm{O})$ at $1,150 \mathrm{~m}$ asl tend to be lower with the increase soil depth. The value of $\mathrm{pH}(\mathrm{H} 2 \mathrm{O})$ at soil surface horizon is lower than the of at profile $\mathrm{P} 3(4,98)$. The value of $\mathrm{pH}(\mathrm{H} 2 \mathrm{O})$ tended to increase with the increase of soil depth. At profile $\mathrm{P} 5(1,350 \mathrm{~m}$ asl) the value of $\mathrm{pH}(\mathrm{H} 2 \mathrm{O})$ subsurface was higher that the value of surface, but decreased with the deeper soil. The value of $\mathrm{pH}(\mathrm{H} 2 \mathrm{O})$ surface horizon $\mathrm{P} 7(1,575 \mathrm{~m}$ asl) has the highest value observed that is 6.25 .

The value of $\mathrm{pH}$ subsurface horizon has a little increase on the top of the soil observed.

We also found the values of soil $\mathrm{pH}(\mathrm{KCl})$ are lower that the value of $\mathrm{pH}(\mathrm{H} 2 \mathrm{O})$. The different value $(-\Delta \mathrm{pH})-$ 0.03 till -1.67 . Uehara \& Gillman [16], pointed out that $-\Delta \mathrm{pH}$ means the soil has negative exchangeable surface complex causing possible Alexch present but a lower number [17].

\section{b. Organic Carbon}

A very high amount of organic carbon (C-organic) content (5.84\%) was found at the surface horizon under the P1 profile (950 m asl). This is the highest value among the 7 profile of all horizons, followed by P5 (1,350 $\mathrm{m}$ asl) totaling $4.50 \%$. The values decrease in order of P2 and P3 (4.42\% and 4.38\%), then P4, P6 and P7 (4.32\%, 4.20 , and $3.66 \%$ ) accordingly. High levels of C-organic on the surface horizon on the P1 profile result in a darker color than other soils. According to Tan (1978), the accumulation of organic material is due to the presence of amorphous clay minerals so that it can be maintained high organic material content.

Table 1. Chemical characteristic of Andisol found under organic coffee plantation at Bener Meriah District.

\begin{tabular}{|c|c|c|c|c|c|c|c|}
\hline \multirow[b]{2}{*}{ Profile } & \multirow[b]{2}{*}{ Horizon } & \multirow[t]{2}{*}{ Depth $(\mathrm{cm})$} & \multicolumn{2}{|c|}{ Soil Acidity $(\mathrm{pH})$} & \multirow{2}{*}{$\begin{array}{c}\Delta \mathrm{pH} \\
(\mathrm{pHKCl}- \\
\left.\mathrm{pH} \mathrm{H} \mathrm{H}_{2} \mathrm{O}\right)\end{array}$} & \multirow[t]{2}{*}{ C-org. (\%) } & \multirow{2}{*}{$\begin{array}{c}\text { CEC } \\
(\mathrm{me} / 100 \\
\mathrm{g})\end{array}$} \\
\hline & & & $\mathrm{H}_{2} \mathrm{O}$ & $\mathrm{KCl}$ & & & \\
\hline \multirow{4}{*}{$\begin{array}{c}\text { P1 } \\
(950 \mathrm{~m} \\
\text { asl) }\end{array}$} & $\mathrm{Ah}$ & $0-25$ & 5.80 & 5.77 & -0.03 & 5.34 & 31.20 \\
\hline & $\mathrm{AB}$ & $25-51$ & 5.50 & 4.75 & -0.75 & 4.50 & 27.60 \\
\hline & Bw1 & $51-118$ & 4.62 & 4.55 & -007 & 3.18 & 22.20 \\
\hline & Bw2 & 118 & 5.69 & 4.65 & -1.04 & 2.45 & 15.80 \\
\hline \multirow{4}{*}{$\begin{array}{c}\mathrm{P} 2 \\
(1,050 \mathrm{~m} \\
\text { asl })\end{array}$} & $\mathrm{Ah}$ & $0-23$ & 4.55 & 4.16 & -0.39 & 4.38 & 33.40 \\
\hline & Bw1 & $23-41$ & 4.72 & 4.70 & -0.02 & 3.14 & 26.60 \\
\hline & Bw2 & $41-93$ & 5.53 & 4.45 & -1.08 & 2.49 & 28.80 \\
\hline & $\mathrm{BC}$ & +93 & 5.04 & 4.50 & -0.54 & 1.48 & 17.20 \\
\hline \multirow[t]{2}{*}{ P3 } & $\mathrm{Ah}$ & $0-37$ & 5.53 & 3.90 & -1.63 & 4.42 & 31.80 \\
\hline & Bw1 & $37-60$ & 5.60 & 3.93 & -1.67 & 4.04 & 26.40 \\
\hline
\end{tabular}




\begin{tabular}{clrlllll}
$(1,150 \mathrm{~m}$ & Bw2 & $60-102$ & 5.58 & 4.67 & -0.91 & 3.99 & 23.40 \\
asl $)$ & BC & +102 & 4.87 & 4.67 & -0.20 & 3.01 & 15.20 \\
\hline P4 & Ah & $0-36$ & 4.98 & 4.58 & -0.40 & 4.32 & 28.80 \\
$(1,250 \mathrm{~m}$ & A1 & $36-57$ & 5.72 & 4.47 & -1.25 & 4.12 & 26.60 \\
asl $)$ & Bw1 & $57-77$ & 5.06 & 4.94 & -0.12 & 5.00 & 22.40 \\
& Bw2 & $77-101$ & 5.50 & 4.75 & -0.75 & 3.60 & 14.40 \\
& BC & +101 & 5.54 & 4.89 & -0.65 & 2.03 & 81.00 \\
\hline P5 & Ah & $0-33$ & 5.88 & 5.36 & -0.52 & 4.50 & 29.60 \\
$(1,350 \mathrm{~m}$ & Bw1 & $33-63$ & 5.65 & 5.19 & -0.46 & 4.00 & 21.80 \\
asl $)$ & Bw2 & $63-86$ & 5.40 & 5.06 & -0.34 & 1.30 & 19.80 \\
& BC & +86 & 5.71 & 5.36 & -0.35 & 2.58 & 16.60 \\
\hline P6 & Ah & $0-24$ & 5.45 & 4.67 & -0.78 & 4.20 & 31.20 \\
$(1,450 \mathrm{~m}$ & AB & $24-47$ & 5.85 & 4.79 & -1.06 & 3.90 & 29.80 \\
asl $)$ & Bw1 & $47-74$ & 5.70 & 4.92 & -0.78 & 2.78 & 21.60 \\
& Bw2 & +74 & 5.00 & 4.96 & -0.04 & 1.54 & 20.20 \\
\hline P7 & Ah & $0-33$ & 5.50 & 4.98 & -0.52 & 3.66 & 27.40 \\
$(1,575 \mathrm{~m}$ & B1 & $99-51$ & 5.75 & 4.98 & -0.77 & 3.33 & 21.60 \\
asl $)$ & B2 & $51-73$ & 5.70 & 4.98 & -0.82 & 2.22 & 24.60 \\
& Bw & $73-128$ & 5.50 & 5.39 & -0.11 & 1.91 & 11.60 \\
& BC & $128-138$ & 5.40 & 5.03 & -0.37 & 1.45 & 12.00
\end{tabular}

Table 1 shows that the $\mathrm{P} 1$ profile with an altitude of $950 \mathrm{~m}$ asl has the highest $\mathrm{C}$-organic content of the other location profile. The high C-organic content of the P1 profile (the lowest altitude) is because the organic matter in the form of coffee skin at P1 is available and weathering process is rapid and intensive, whereas, in the profile located at a higher altitude, the weathering process is slower so that the C-organic content is lower. Karim[18] stated that the difference in altitude above sea level shows a negative relationship with C-organic levels where the higher the altitude, the lower the C-organic content.

\section{c. Cation Exchange Capacity}

The cation exchange capacity (CEC) shows the ability of a land exchange complex to absorb and exchange cations. The cation exchange capacity on the surface horizon profile P1 (950 m asl) is high, ie $31.20 \mathrm{me} / 100 \mathrm{~g}$ and CEC on the Ah profile horizon P2 (1,050 m asl) is very high, ie $33.40 \mathrm{me} / 100 \mathrm{~g}$ which is the highest CEC value of all horizons among the 7 profiles observed. The next sequence was found at P3 (1,150 m asl), which was $31.80 \mathrm{me} / 100 \mathrm{~g}$, then decreased on P5 and P4 profiles, ie $29.60 \mathrm{me} / 100 \mathrm{~g}$ and $28.80 \mathrm{me} / 100 \mathrm{~g}$, then P6 profile and P7, ie $31.20 \mathrm{me} / 100 \mathrm{~g}$ and $27.40 \mathrm{me} / 100 \mathrm{~g}$. The high value of CEC in the surface horizon on each profile relates to the soil C-organic content, where high levels of C-organic in Andisol soil are found in the upper layers. It is known that organic matter has a large CEC, so it can cause increased soil CEC.

The dominance of Humic Acid and Fulvic Acid

This soil profile is located in the Village of Mangku, Bandar SubDistrict at an altitude of $950 \mathrm{~m}$ asl with slopes $>30 \%$ (Table 2). The soil was classified as Aquic Hapludand. In the surface horizon, the content of fulvic acid is higher than humic acid and decreases to a depth of $118 \mathrm{~cm}$, while humic acid content increases in the lower layer and is found to be higher than fulvic acid (Fig. 1). 
Table 2. Result of analysis of organic fractions of Andisol

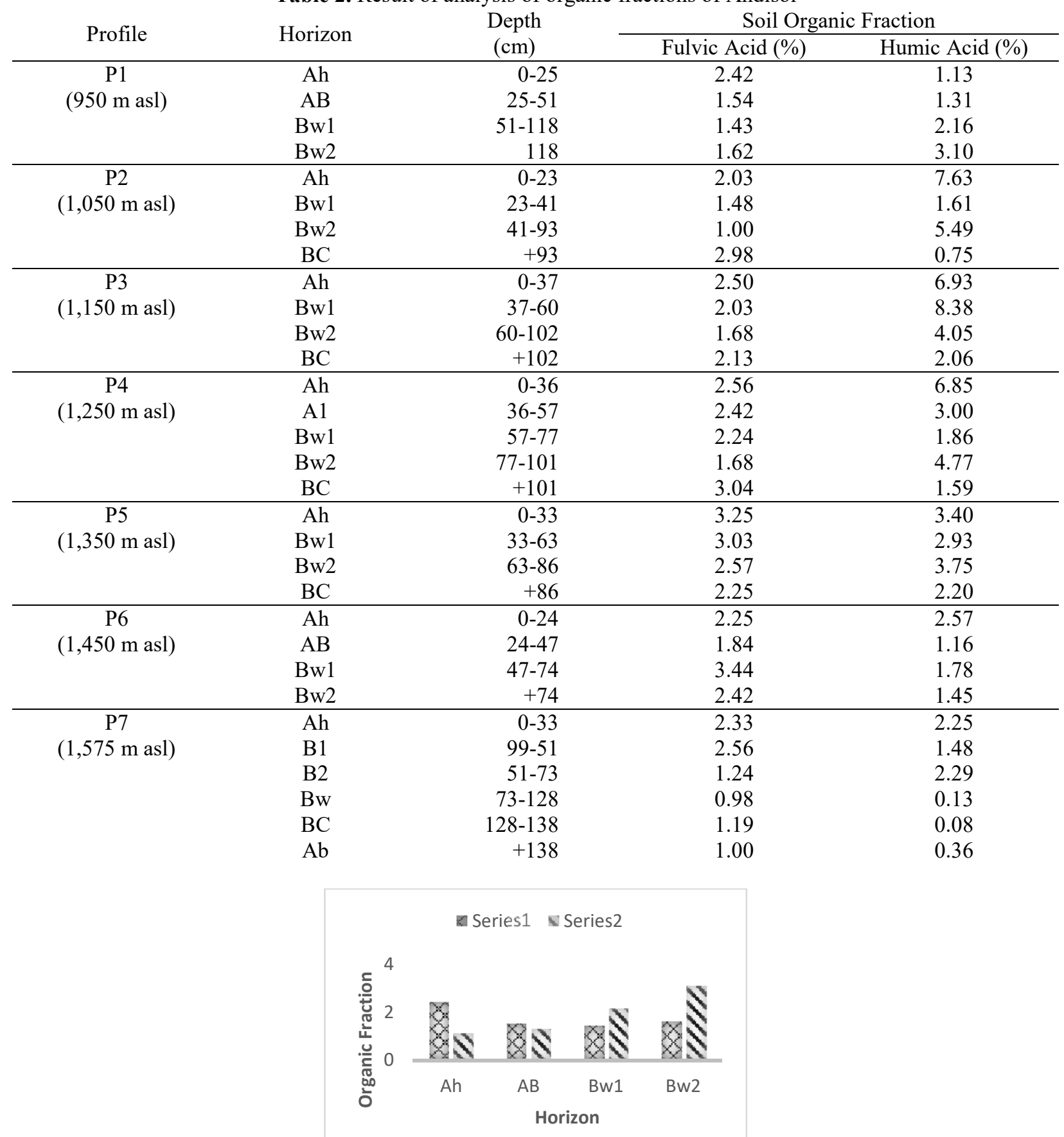

Figure 1. The content of humic acid (HA)and fulvic Acid (HA) on Andisol organic arabica coffee plant at altitude $950 \mathrm{~m}$ above sea level ( $\mathrm{m}$ asl) 
The highest content of fulvic acid is found at a depth of $0-25 \mathrm{~cm}$, ie $2.42 \%$. This may be due to the decomposed organic material found in surface horizons. At this location, the management of organic material was done by giving the skin of coffee and Lamtoro cuttings to the soil surface since 1992, and profile 2 is located in the village area of Genteng Rapi Subdistrict at an altitude of 1,050 $\mathrm{m}$ asl with slope 8 - 15\%, Typic Hapludand soil classification. In contrast to the $\mathrm{P} 1$ profile, the $\mathrm{P} 2$ profile has a humic acid on the surface horizon more dominant than fulvic acid, and its distribution according to the soil depth varied greatly. Humic acid content was lower in the lower horizon. The highest content of fulvic acid was found in $\mathrm{BC}(93 \mathrm{~cm})$ horizon, which is $2.98 \%$. The content decreased towards the surface layer (Fig. 2). This is because the location was planted by Vetiver grass, provision of organic ingredients of coffee skin, and its location lies on the slope of 8 - 15\% (wavy). It was also assumed that the Vetiver grass root zone and its soil morphology affected the soil fulvic acid.

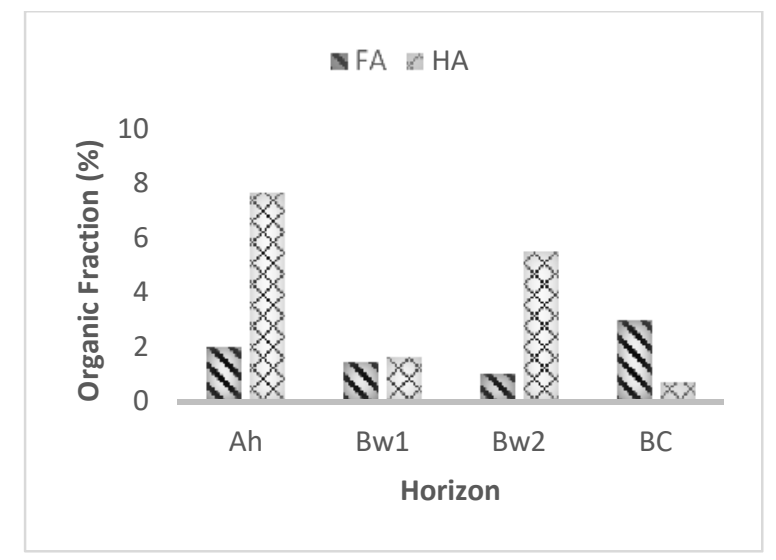

Figure 2. The content of humic acid (HA) and fulvic acid (FA) on Andisol organic arabica coffee plant at altitude of $1,050 \mathrm{~m}$ asl

Profile of P3 is located in Sidodadi Village, Bandar Subdistrict at an altitude of 1,150 m asl with slope $0-3 \%$, Typic Hapludand. In each horizon, the humic acid content was more dominant than fulvic acid except the $\mathrm{BC}$ horizon $(102 \mathrm{~cm})$. The highest humic acid content was found on the subsurface horizon, the content was decreasing regularly as the soil went deeper. The highest content of fulvic acid was found in the upper horizon of $2.50 \%$ (Fig. 3). The P3 profile had the highest humic acid content of all layers compared to other research sites. This is caused by the provision of organic material that comes from the supplying skin of coffee more intensively. 


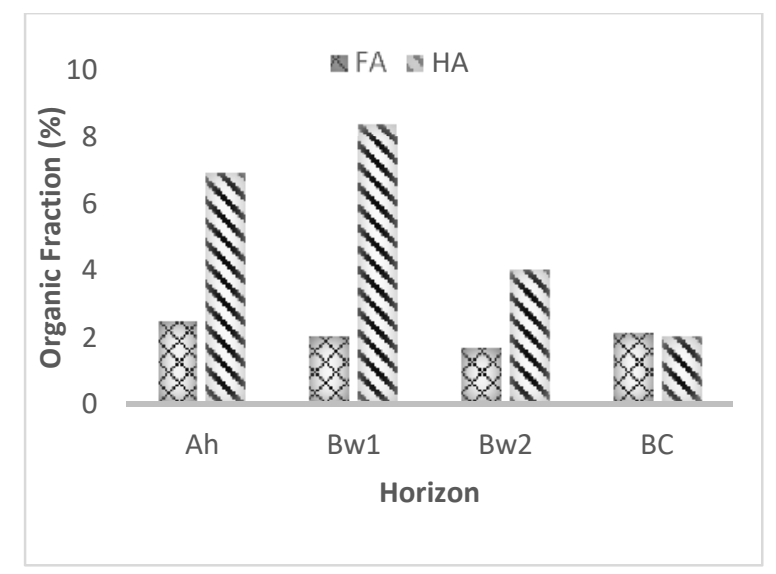

Figure 3. The content of humic acid (HA) and fulvic acid (FA) on Andisol organic arabica coffee plant at altitude of $1,150 \mathrm{~m}$ asl.

Profile P4 is located in Kramat Jaya Village, Bandar SubDistrict at an altitude of 1,250 m asl with slopes 0 - 3\%, Typic Hapludand. In the Ah horizon, the humic acid content was higher than the fulvate and decreased to a depth of $101 \mathrm{~cm}$ (Table 2). Its extents to the depth of the soil were highly fluctuating (Fig. 4). However, the fulvic acid content was increasing in the lower layer and the highest content was found in $\mathrm{BC}(101 \mathrm{~cm})$ horizon, which was $3.04 \%$. This showed that the farther away from the soil surface activity of microorganisms decreased. The content of decomposed organic matter was also decreasing.

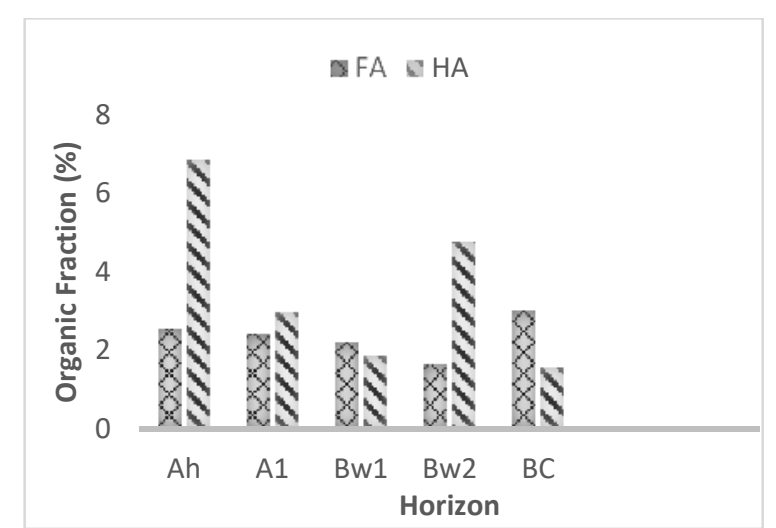

Figure 4. The content of humic acid (HA) and fulvic acid (FA) on Andisol organic arabica coffee plant at an altitude of $1,250 \mathrm{~m}$ asl.

Profile P5 is located in the Village Pondok Gajah, SubDistrict Bandar at an altitude of 1,350 $\mathrm{m}$ asl with slopes $0-3 \%$, Typic Hapludand. On the Ah, a humic acid content was found slightly higher than fulvic acid, which is $3.40 \%$ and $3.25 \%$ and decreased irregularly to a depth of 86 $\mathrm{cm}$, while the highest fulvic acid content was found in surface horizon $(0-33 \mathrm{~cm})$, ie $3.25 \%$. 


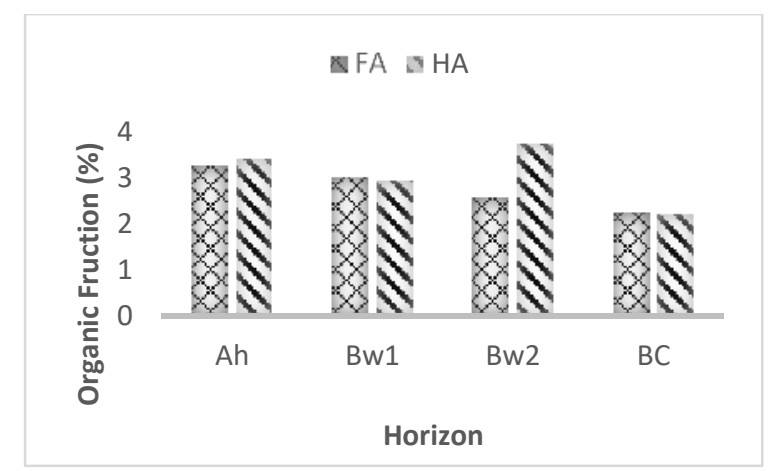

Figure 5. The content f Humic acid (HA) and fulvic acid (FA) content in Andisol organic arabica coffee plantation at altitude $1,350 \mathrm{~m}$ asl.

Profile 6 is located in Panji Mulia, Bukit SubDistrict at an altitude of 1,450 m asl with slope $8-15 \%$, and Typic Hapludand. The humid acid content was higher than fulvic acid, $2.57 \%$ and decreased according to the depth of soil, while the fulvic acid content increased in the Bw1 horizon (47 - $74 \mathrm{~cm}$ ), ie $3.44 \%$ (Fig. 6). This is because at that location added organic ingredients in the form of coffee skin continuously.

Profile 7 is located in the village of Sidoarjo Bukit SubDistrict at an altitude of $1,575 \mathrm{~m}$ asl with slopes $>30 \%$, Typic Hapludan. In each horizon, the content of fulvic acid was more dominant than humic acid except on the B2 horizon $(51-73 \mathrm{~cm})$ (Fig. 7). A greater decreased in humic acid was found in the BC horizon $(128-138 \mathrm{~cm})$.

There is a tendency of higher profile location from sea level, fulvic acid content gets increased and vice versa humic acid decreased.

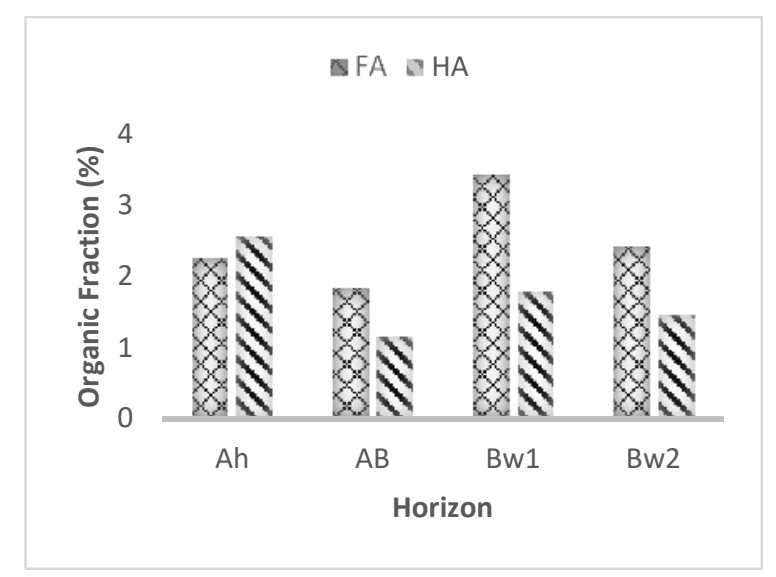

Figure 6. The content of humic acid (HA) and fulvic acid (FA) on Andisol organic arabica coffee plant at altitude $1,450 \mathrm{~m}$ asl. 


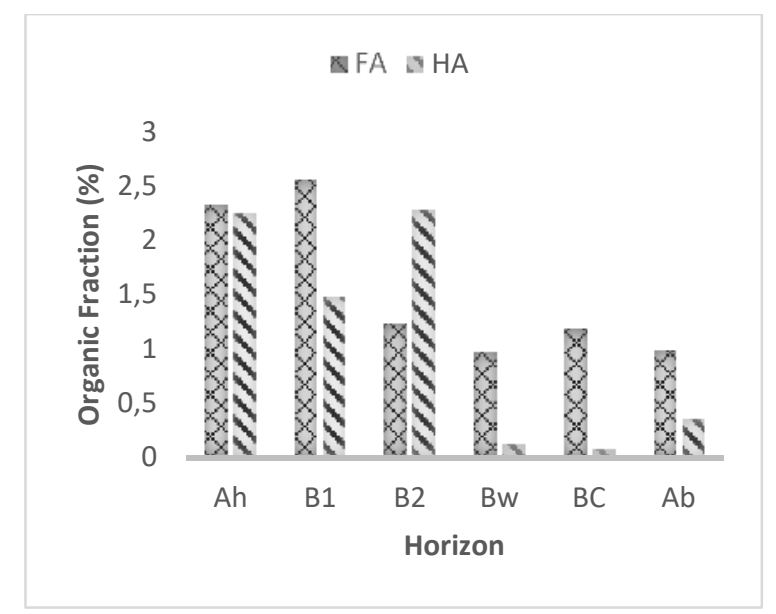

Figure 7. The content of humic acid (HA) and fulvic acid (HA)on Andisol organic arabica coffee plant at altitude $1,575 \mathrm{~m}$ asl.

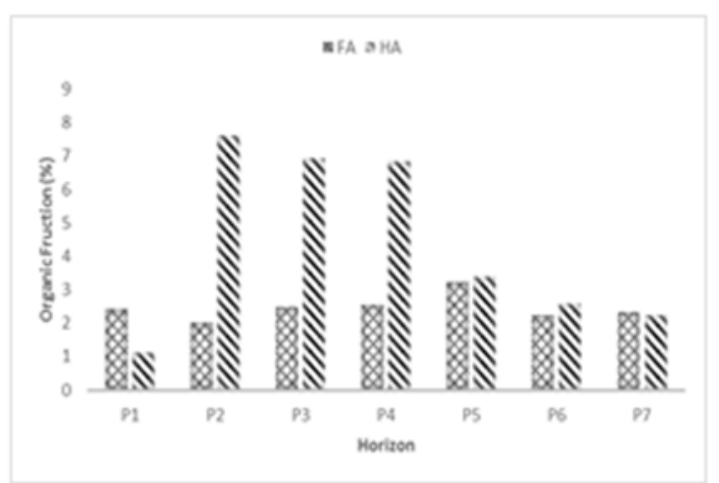

Figure 8. Presence of fulvic acid (FA) and humic acid (HA) on different surface horizons at each altitude.

\section{Conclusion}

The content of fulvic acid and humic acid differs on each horizon and among altitudes on the Andisol grown under organic arabica coffee plantation. Humic acid content on the surface horizon ranges from low to high. The highest humic acid content was found on the surface horizon at an altitude of $1050 \mathrm{~m}$ asl. The higher the altitude, the humic acid content decreases on the surface horizon. The highest content of fulvic acid was found at an altitude of $1,450 \mathrm{~m}$ asl that is on the Bw1 horizon of $3.44 \%$.

\section{REFERENCES}

[1] R. A. Dahlgren, M. Saigusa, and F. C. Ugolini, "The nature, properties and management of volcanic soils," Adv. Agron., vol. 82, pp. 113-185, 2004.

[2] H. L. Bohn, "Estimate of organiccarbon in world Soils1," Soil Sci. Soc. Amer. J., vol. 
40, no. 3, pp. 466-470, 1976.

[3] B. Minasny and A. B. Mcbratney, "Limited effect of organic matter on soil available water capacity," Eur. J. Soil Sci., 2017.

[4] S. M. Griffith and M. Schnitzer, "Analytical Characteristics of Humic and Fulvic Acids Extracted from Tropical Volcanic Soils," Soil Sci. Soc. Amer. J., vol. 39, no. 5, pp. 861867, 1975.

[5] M. Schnitzer, "Humic substances: Chemistry and reactions," in Soil Organic Matter. Development of soil sci, 4th Impres., M. Schnitzer and S. U. Khan, Eds. United Kingdom: Elsevier Scientific Publ. Company., 1989, pp. 1-64.

[6] Y. Yanagi, S. Nishimura, and H. Shindo, "Geoderma regional fire-induced formation and biodegradation of humic substances in Andosols of Japan," GEODRS, vol. 7, no. 2, pp. 177-186, 2016.

[7] S. Shoji, R. Dahlgren, and M. Nanzyo, "Genesis of volcanic ash soils," in Volcanic ash soils: genesis, properties and utilization, Amsterdam: Elsevier; Developments in Soil Science, 21, 1993, pp. 37-71.

[8] M. J. Kimsey, M. T. Garrison-Johnson, and L. Johnson, "Characterization of volcanic ash - influenced forest soils across a geoclimatic sequence," Soil Sci. Soc. Am. J., vol. 75, pp. 267-279, 2011.

[9] F. Bartoli, A. J. Poulenard, and B. E. Schouller, "Influence of allophane and organic matter contents on surface properties of Andisols," Eur. J. Soil Sci., vol. 58, pp. 450 464, 2007.

[10] A. Karim, Sugianto, and S. Handayani, "Karakterisasi dan klasifikasi tanah andisol Aceh Tengah,” J. Agrista, vol. 2, no. 2, pp. 110-119, 1998.

[11] A. Karim, "Evaluasi kesesuaian lahan kopi arabika yang dikelola secara organik pada tanah andisol di Aceh Tengah," Institut Pertanian Bogor, 1999.

[12] K. H. Tan, "Variations in soil humic compounds as related to regional and analytical differences," Soil Sci., vol. 125, no. 6, 1978.

[13] M. Nanzyo, R. Dahlgren, and S. Shoji, "Chemical Characteristics of Volcanic Ash Soils," in Volcanic Ash Soils, vol. 21, S. Shoji, M. Nanzyo, and R. B. T.-D. in S. S. Dahlgren, Eds. Amsterdam: Elsevier; Developments in Soil Science, 21, 1993, pp. 145-187.

[14] G. W. Thomas and W. L. Hargrove, "The chemistry of soil acidity," in Soil acidity and liming, 2nd ed., F. Adams, Ed. Wisconsin, USA: ASA CSSA and SSSA, 1984, pp. 356.

[15] R. Hardjosoesastro, H. Suyanto, and A. M. Satari, "Andisol dari daerah Sukamantri kabupaten Bogor," Pen. Tanah dan Pupuk, vol. 2, pp. 18-19, 1982.

[16] G. Uehara and G. Gillman, The mineralogy, chemistry, and physic of tropycal soil with variable charge clays. Colorado: Wesrview Press/Boulder, 1981.

[17] S. Hardjowigeno, Klasifikasi tanah dan pedogenesis, 1st ed. Tangerang Selatan: Akademika Pressindo, 1993.

[18] A. Karim, "Evaluasi kriteria kesesuaian lahan tanaman kopi arabika di Aceh Tengah," Institut Pertanian Bogor, 1993. 